Article

\title{
Fungal Communities Associated with Peacock and Cercospora Leaf Spots in Olive
}

\author{
Carla M.R. Varanda ${ }^{1, *(\mathbb{D}}$, Patrick Materatski ${ }^{1}\left(\mathbb{D}\right.$, Miguel Landum ${ }^{2}$, Maria Doroteia Campos ${ }^{1} \mathbb{C}$ \\ and Maria do Rosário Félix ${ }^{3}$ \\ 1 ICAAM - Instituto de Ciências Agrárias e Ambientais Mediterrânicas, Instituto de Investigação e Formação \\ Avançada, Universidade de Évora, Polo da Mitra, Ap. 94, 7006-554 Évora, Portugal; \\ pmateratski@uevora.pt (P.M.); mdcc@uevora.pt (M.D.C.) \\ 2 Instituto de Tecnologia Química e Biológica António Xavier, Universidade Nova de Lisboa, Av. da República, \\ 2780-157 Oeiras, Portugal; miguel.landum@gmail.com \\ 3 Departamento de Fitotecnia, ICAAM - Instituto de Ciências Agrárias e Ambientais Mediterrânicas, Escola de \\ Ciências e Tecnologia, Universidade de Évora, Polo da Mitra, Ap. 94, 7006-554 Évora, Portugal; \\ mrff@uevora.pt \\ * Correspondence: carlavaranda@uevora.pt; Tel.: +351-266-760-852
}

Received: 21 May 2019; Accepted: 10 June 2019; Published: 12 June 2019

\begin{abstract}
Venturia oleaginea and Pseudocercospora cladosporioides are two of the most important olive fungal pathogens causing leaf spots: peacock spot, and cercosporiosis, respectively. In the present study, fungal communities associated with the presence of these pathogens were investigated. Overall, 300 symptomatic and asymptomatic trees from different cultivars were sampled from Alentejo, Portugal. A total of 788 fungal isolates were obtained and classified into 21 OTUs; Ascomycota was clearly the predominant phylum (96.6\%). Trees from cultivar 'Galega vulgar' showed a significant higher fungal richness when compared to 'Cobrançosa', which in turn showed significant higher values than 'Picual'. Concerning plant health status, symptomatic plants showed significant higher fungal richness, mainly due to the high number of isolates of the pathogens $V$. oleaginea and $P$. cladosporioides. In terms of fungal diversity, there were two major groups: ca. $90 \%$ of the isolates found in symptomatic plants belonged to V. oleaginea, P. cladosporioides, Chalara sp., and Foliophoma sp. while ca. 90\% of the isolates found in asymptomatic plants, belonged to Alternaria sp. and Epicoccum sp. This study highlights the existence of different fungal communities in olive trees, including potential antagonistic organisms that can have a significant impact on diseases and consequently on olive production.
\end{abstract}

Keywords: biocontrol; fungal communities; ITS-PCR; Pseudocercospora cladosporioides; Venturia oleaginea

\section{Introduction}

Olive (Olea europaea L.) is one of the most important fruit crops in countries characterized by Mediterranean climates and has been expanding in the last few years in producing countries and also to other countries such as Argentina, China, and India [1,2]. The growing awareness of the human health benefits associated with olive oil consumption is the main reason for this expansion. In Portugal, in addition to the high economic impact, olive has also significant environmental, social, and landscape impacts. The Alentejo region, benefiting from the biggest water reservoir in Western Europe built in the beginning of this century, the Alqueva dam, has rapidly seen the increase of super intensive olive orchards and is now responsible for the production of over $70 \%$ of the national olive oil. The Portuguese cultivars 'Galega vulgar' and 'Cobrançosa', and the Spanish cultivar 'Picual' are three of 
the most cultivated varieties, including in the Alentejo region, mainly due to the unique characteristics and properties of the olive oil they produce.

As in many other crops, the olive is susceptible to several pathogens that may affect the yield and quality of its products, with significant economic impacts [3,4]. Two of the most important and widespread fungal pathogens attacking the olive canopy are Venturia oleaginea and Pseudocercospora cladosporioides, responsible for peacock spot and cercosporiosis, respectively $[5,6]$. Both pathogens cause olive leaf spots, which are frequently difficult to distinguish [7]. Symptoms caused by V. oleaginea mainly start as sooty blotches on the upper surface of leaves that develop into dark green to black circular spots 0.2 to $1 \mathrm{~cm}$ in diameter, often surrounded by a yellowish halo around the spot [8-10]. Symptoms caused by $P$. cladosporioides in leaves are irregular chlorotic areas that turn necrotic in the upper surface and in the lower surface, grey areas corresponding to asexual fruiting structures $[5,11,12]$. In both cases, under favorable conditions, sunken brown lesions may appear on petioles and fruits. Trees affected by olive leaf spots caused by V. oleaginea and P. cladosporioides show defoliation of leaves and weakness or death of branches, resulting in reduced fruit set and a decrease in oil yield in the following years [13-18]. These fungi survive in leaf lesions and spread through conidia, by rain, wind, or insects, which is the main source of inoculum for primary infection in spring $[19,20]$. Both infections are associated with high humidity and low temperatures [7,19,21-23]. The establishment of several new super intensive olive orchards originates in a greater shading of the trees and favors the conditions for the development of these diseases. In highly susceptible cultivars, a complete loss of yield can occur under favorable climatic conditions. Currently, control measures are mostly based on chemical fungicides that are only partially effective if applied at the correct time and if disease risk is low; furthermore their frequent misapplication represent high costs and is harmful to human health and the environment [4,8,24]. According to the Directive 2009/128/EC, the European Model for Agriculture requires sustainable production systems and plant protection methods must obey the guidelines for integrated production of olives [25]. Studies concerning the evaluation of cultivars susceptibility to Cercosporiosis are scarce and many cultivars are considered as susceptible [26]. As for $V$. oleaginea, Roca and co-authors [27] determined the susceptibility of several cultivars under normal conditions, where 'Galega vulgar' was considered resistant, 'Cobrançosa' was moderately susceptible and 'Picual' was highly susceptible [5]. However, the recommendation of the use of resistant cultivars is difficult to follow by the producers, as they do not want to lose the specific quality and yield characteristics of a given cultivar. In addition, complete resistance is sometimes difficult to achieve. Thus, there is a need to develop alternative and effective control strategies that are safe for humans and the environment. In that sense, the study of microorganisms associated with specific pathogens will facilitate the understanding of their complex interactions, including the finding of potential antagonists that may be explored for designing new effective biological strategies for the control of the diseases, resulting in more sustainable systems. Although available data on fungal communities inhabiting the olive phyllosphere is still lacking, in the last few years there has been an increased interest on their study, due to the potential use of these fungi as biocontrol agents [28-30]; however little is known about the associations they establish with known pathogens.

This work aimed to investigate the richness and diversity of fungal communities associated with symptomatic olive plants, with leaf spots caused by $V$. oleaginea and/or P. cladosporioides, and asymptomatic olive plants, without apparent symptoms. In addition, fungal communities associated with three olive cultivars with different susceptibilities to these diseases were evaluated, namely 'Galega vulgar', 'Cobrançosa,' and 'Picual'. Consequently, it was hypothesized that the health status and type of cultivar could contribute to the differences in the fungal communities in terms of richness and diversity. The following research questions were addressed: Do the fungal richness and diversity vary (i) according to the different health status and (ii) among the different olive cultivars? This knowledge will contribute in determining the fungal strains that may naturally present an antagonistic effect against these pathogens and consequently will contribute to obtain more sustainable systems 
for plant production, such as the management of host-microbe interactions for improvement of plant protection and consequently crop yields.

\section{Results}

\subsection{Fungal Identification-Structural Diversity}

A total of 300 olive trees sampled (100 trees $\times 3$ cultivars), half presenting leaf spots and half with apparently no symptoms, allowed the identification of 788 fungal isolates, either from fungal isolation in vitro or from direct leaf DNA. All fungi generated ITS amplification products with size ranging from 500 to $700 \mathrm{bp}$ that were assigned to 21 OTUs: Alternaria sp., Arthrinium sp., Aspergillus sp., Aureobasidium sp., Botrytis sp., Bullera sp., Chaetomium sp., Chalara sp., Cryptococcus sp., Diaporthe sp., Epicoccum sp., Erythrobasidium sp., Fusarium sp., Fusicladium sp., Neofusicoccum sp., Nigrospora sp., Foliophoma sp., P. cladosporioides, Saccharata sp., V. oleaginea and Sporobolomyces sp. All isolates were identified to genus level with $>97 \%$ identity. V. oleaginea and P. cladosporioides were identified to species level, with 100\% identity to sequences in the GenBank (Accession number AF338403.1 for V. oleaginea and MH856296.1 and AY438248.1 for P. cladosporioides). The same OTU within a sample was considered as a single isolate.

The amplification of total DNA from fungal cultures, allowed the identification of 11 OTUs and the amplification of total DNA from leaf tissues, allowed the identification of 19 OTUs. Fusarium sp. and Nigrospora sp. were identified only when fungal cultures were used. On the other hand, Arthrinium sp., Bullera sp., Chaetomium sp., Chalara sp., Cryptococcus sp., Erythrobasidium sp., Neofusicoccum sp., Sporobolomyces sp., P. cladosporioides, and V. oleaginea did not grow in vitro and were only identified when DNA from leaf tissues was used.

Overall, nearly all isolates obtained belong to Phylum Ascomycota (96.6\%), represented by four classes, with the class Dothideomycetes the most representative (70.2\%), followed by Leotiomycetes $(14.5 \%)$, Sordariomycetes $(10.0 \%)$, and Eurotiomycetes (1.9\%). An amount of $3.4 \%$ of the isolates belongs to Phylum Basidiomycota, represented by three classes, class Tremellomycetes $(2.3 \%)$, Microbotryomycetes $(0.63 \%)$, and Cystobasidiomycetes $(0.51 \%)$. Seven genera Venturia $(16.0 \%)$, Alternaria (15.0\%), Epicoccum (13.8\%), Pseudocercospora (13.2\%), Chalara (11.0\%), Foliophoma (8.4\%), and Botrytis (3.4\%) together comprised nearly $80 \%$ of the fungal diversity found.

Univariate and multivariate analyses were performed to detect significant differences in total richness in the endophytic fungi in the two factors "Health status" and "Cultivar". SIMPER analysis on asymptomatic data revealed that only three fungal OTUs Alternaria sp. (62.8\%), Epicoccum sp. (29.1\%), and Arthrinium sp. (2.1\%) represent $94.0 \%$ of the similarities (Table 1 ).

Table 1. Fungal OTUs identified by SIMPER analysis that contribute most to the similarities at each; health status (Asymptomatic and symptomatic) and cultivar ('Galega vulgar', 'Cobrançosa' and 'Picual'). Bold values highlight values higher than $0.05 \%$.

\begin{tabular}{|c|c|c|c|c|c|c|c|c|}
\hline \multirow{4}{*}{$\begin{array}{c}\text { Fungal } \\
\text { OTUs }\end{array}$} & \multicolumn{2}{|c|}{ Asymptomatic Symptomatic } & \multicolumn{2}{|c|}{ Galega Vulgar } & \multicolumn{2}{|c|}{ Cobrançosa } & \multicolumn{2}{|c|}{ Picual } \\
\hline & - & - & Asymptomatic & Symptomatic & Asymptoma & Symptomatic & Asymptom & Symptomatic \\
\hline & \multicolumn{8}{|c|}{ Similarity } \\
\hline & $37.40 \%$ & $51.20 \%$ & $48.09 \%$ & $61.54 \%$ & $38.18 \%$ & $59.37 \%$ & $30.78 \%$ & $55.24 \%$ \\
\hline Alternaria sp. & 62.81 & 0.75 & 56.18 & 0.92 & 77.48 & 0.74 & 49.28 & 0.22 \\
\hline $\begin{array}{l}\text { Epicoccum } \\
\text { sp. }\end{array}$ & 29.11 & 3.37 & 37.42 & 4.2 & 10.1 & 3.22 & 43.82 & 1.41 \\
\hline $\begin{array}{l}\text { Arthrinium } \\
\text { sp. }\end{array}$ & 2.06 & 0.00 & 1.81 & 0.00 & 2.35 & 0.00 & 1.33 & 0.00 \\
\hline $\begin{array}{l}\text { Chaetomium } \\
\text { sp. }\end{array}$ & 1.83 & 0.00 & 0.97 & 0.00 & 3.35 & 0.00 & 0.93 & 0.00 \\
\hline Diaporthe sp. & 1.68 & 0.00 & 0.86 & 0.00 & 1.28 & 0.00 & 2.71 & 0.00 \\
\hline $\begin{array}{l}\text { Aspergillus } \\
\text { sp. }\end{array}$ & 1.10 & 0.00 & 0.19 & 0.00 & 5.28 & 0.00 & 0.00 & 0.00 \\
\hline
\end{tabular}


Table 1. Cont.

\begin{tabular}{|c|c|c|c|c|c|c|c|c|}
\hline \multirow{4}{*}{$\begin{array}{l}\text { Fungal } \\
\text { OTUs }\end{array}$} & \multicolumn{2}{|c|}{ Asymptomatic Symptomatic } & \multicolumn{2}{|c|}{ Galega Vulgar } & \multicolumn{2}{|c|}{ Cobrançosa } & \multicolumn{2}{|c|}{ Picual } \\
\hline & - & - & \multicolumn{2}{|c|}{ Asymptomatic Symptomatic } & \multicolumn{2}{|c|}{ Asymptomatic Symptomatic } & \multicolumn{2}{|c|}{ Asymptomatic Symptomatic } \\
\hline & \multicolumn{8}{|c|}{ Similarity } \\
\hline & $37.40 \%$ & $51.20 \%$ & $48.09 \%$ & $61.54 \%$ & $38.18 \%$ & $59.37 \%$ & $30.78 \%$ & $55.24 \%$ \\
\hline Fusarium sp. & 0.68 & 0.00 & 0.96 & 0.00 & 0.09 & 0.00 & 0.83 & 0.00 \\
\hline $\begin{array}{l}\text { Nigrospora } \\
\text { sp. }\end{array}$ & 0.60 & 0.00 & 0.62 & 0.00 & 0.07 & 0.00 & 1.11 & 0.00 \\
\hline $\begin{array}{l}\text { Aureobasidium } \\
\text { sp. }\end{array}$ & 0.14 & 0.21 & 0.99 & 0.02 & 0.00 & 0.12 & 0.00 & 0.42 \\
\hline Botrytis sp. & 0.00 & 1.16 & 0.00 & 6.03 & 0.00 & 0.1 & 0.00 & 0.00 \\
\hline Bullera sp. & 0.00 & $<0.05$ & 0.00 & 0.23 & 0.00 & 0.00 & 0.00 & 0.00 \\
\hline Chalara sp. & 0.00 & 16.99 & 0.00 & 22.73 & 0.00 & 34.46 & 0.00 & 0.73 \\
\hline $\begin{array}{l}\text { Cryptococcus } \\
\text { sp. }\end{array}$ & 0.00 & 0.26 & 0.00 & 1.99 & 0.00 & 0.00 & 0.00 & 0.00 \\
\hline $\begin{array}{l}\text { Erythrobasidium } \\
\text { sp. }\end{array}$ & 0.00 & $<0.05$ & 0.00 & 0.00 & 0.00 & 0.00 & 0.00 & 0.21 \\
\hline $\begin{array}{l}\text { Fusicladium } \\
\text { sp. }\end{array}$ & 0.00 & $<0.05$ & 0.00 & 0.64 & 0.00 & 0.00 & 0.00 & 0.00 \\
\hline $\begin{array}{l}\text { Neofusicoccum } \\
\text { sp. }\end{array}$ & 0.00 & $<0.05$ & 0.00 & 0.00 & 0.00 & $<0.05$ & 0.00 & 0.00 \\
\hline $\begin{array}{l}\text { Foliophoma } \\
\text { sp. }\end{array}$ & 0.00 & 9.52 & 0.00 & 19.88 & 0.00 & 0.00 & 0.00 & 18.38 \\
\hline $\begin{array}{c}P . \\
\text { cladosporioides }\end{array}$ & 0.00 & 27.14 & 0.00 & 16.49 & 0.00 & 23.97 & 0.00 & 33.36 \\
\hline Saccharata sp. & 0.00 & $<0.05$ & 0.00 & 0.14 & 0.00 & 0.00 & 0.00 & 0.00 \\
\hline V. oleaginea & 0.00 & 40.42 & 0.00 & 26.52 & 0.00 & 37.35 & 0.00 & 45.27 \\
\hline $\begin{array}{l}\text { Sporobolomyces } \\
\text { sp. }\end{array}$ & 0.00 & $<0.05$ & 0.00 & 0.22 & 0.00 & 0.00 & 0.00 & 0.00 \\
\hline
\end{tabular}

SIMPER analysis on symptomatic data revealed that four fungal OTUs $V$. oleaginea (40.4\%), $P$. cladosporioides (27.1\%), Chalara sp. (17.0\%) and Foliophoma sp. (9.5\%) represent $94.0 \%$ of the similarities (Table 1). In addition, SIMPER analysis revealed that only three OTUs Alternaria sp., Epicoccum sp. and Aureobasidium sp. were present in both symptomatic and asymptomatic olive trees. Twelve OTUs Botrytis sp., Bullera sp., Chalara sp., Cryptococcus sp., Erythrobasidium sp., Fusicladium sp., Neofusicoccum sp., Foliophoma sp., P. cladosporioides, Saccharata sp., V. oleaginea, and Sporobolomyces sp. were exclusive of the symptomatic olive leaves and six OTUs Arthrinium sp., Aspergillus sp., Chaetomium sp., Diaporthe sp., Fusarium sp., and Nigrospora sp. were exclusive of the asymptomatic olive leaves. SIMPER analysis on 'Galega vulgar' revealed seven fungal OTUs: Alternaria sp. (26.94\%), Epicoccum sp. (25.95\%), V. oleaginea (12.46\%), Chalara sp. (10.68\%), Foliophoma sp. (9.34\%), P. cladosporioides (7.75\%), and Botrytis sp. (2.83\%) that represent $95.9 \%$ of the similarities (Table 1). On 'Cobrançosa', data revealed the presence of five fungal species: Alternaria sp. (33.66\%), V. oleaginea $(20.06 \%)$, Chalara sp. $(18.51 \%), P$. cladosporioides (12.87\%), and Epicoccum sp. (10.46\%) that represent $95.5 \%$ of the similarities (Table 1). On 'Picual' five fungal OTUs V. oleaginea (26.17\%), Epicoccum sp. (21.89\%), P. cladosporioides (19.29\%), Alternaria sp. (19.02\%), and Foliophoma sp. (10.63\%) represent $96.9 \%$ of the similarities (Table 1). At cultivar level, SIMPER analysis revealed that thirteen OTUs Alternaria sp., Arthrinium sp., Aspergillus sp., Aureobasidium sp., Botrytis sp., Chaetomium sp., Chalara sp., Diaporthe sp., Epicoccum sp., Fusarium sp., Nigrospora sp., P. cladosporioides, and V. oleaginea were present in 'Galega vulgar', 'Cobrançosa' and 'Picual'. 'Galega vulgar' presented five OTUs exclusively; Bullera sp., Cryptococcus sp., Fusicladium sp., Saccharata sp., and Sporobolomyces sp. One OTU, Neofusicoccum sp. was exclusive in 'Cobrançosa' and one OTU Erythrobasidium sp. was exclusive in 'Picual'.

\subsection{Multivariate Data Analysis-Fungal Richness}

The mean fungal richness \pm SE was $1.79 \pm 0.07$ in asymptomatic olive plants and $3.47 \pm 0.13$ in symptomatic (Figure 1-I). PERMANOVA analyses showed significantly higher fungal richness 
in symptomatic olive plants (Factor "health status", $\mathrm{p}=0.0166$ ) (Table 2) when compared to asymptomatic plants.
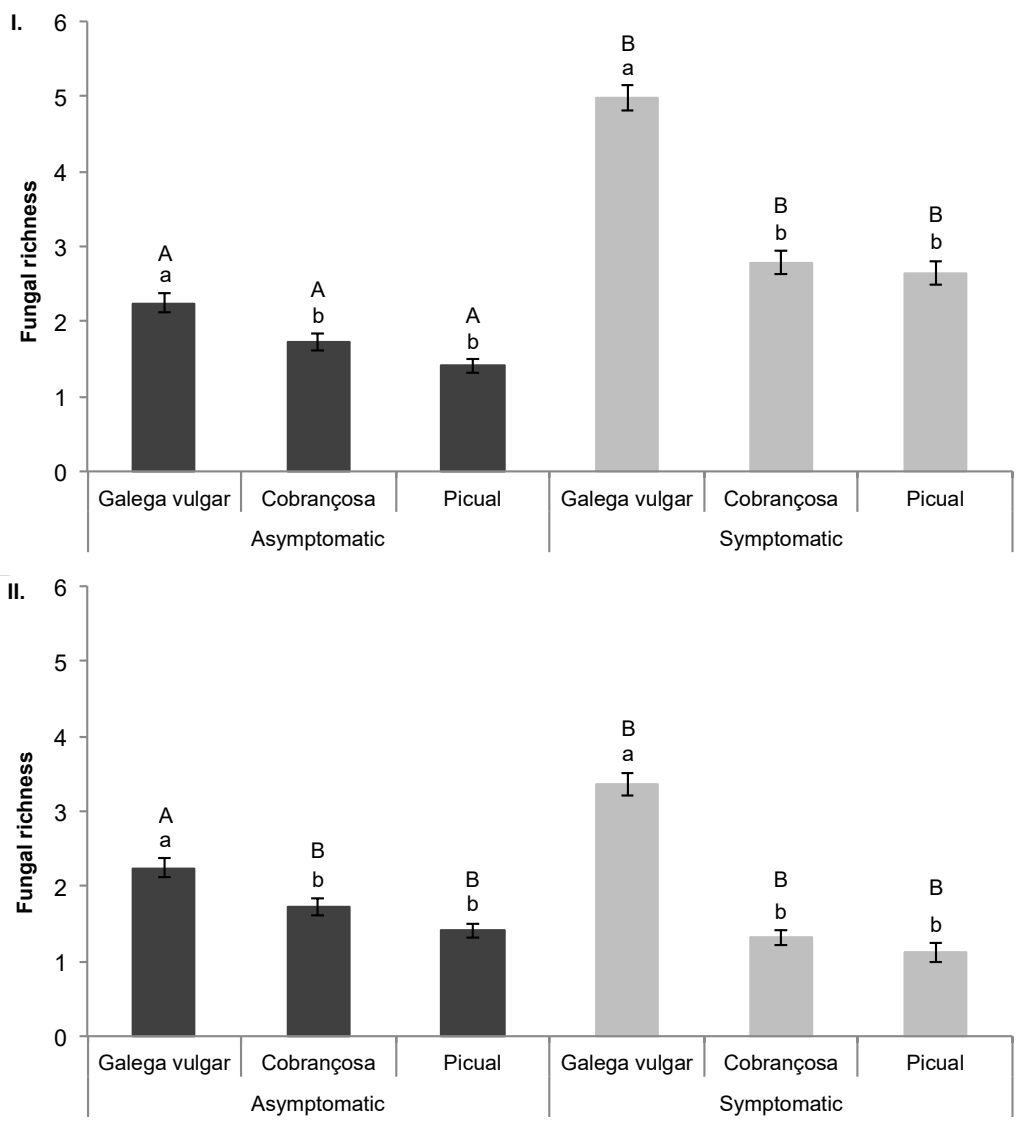

Figure 1. Mean fungal richness \pm standard error (SE) at each: health status (asymptomatic and symptomatic) and cultivar ('Galega vulgar', 'Cobrançosa' and 'Picual'). Different letters indicate significant differences $(p<0.05)$ and equal letters indicate no significant differences $(p>0.05)$. Lowercase letters indicate comparisons between cultivars ('Galega vulgar', 'Cobrançosa', and 'Picual') within each Health status (asymptomatic or symptomatic). Capital letters indicate comparisons between the same cultivar ('Galega vulgar', 'Cobrançosa', and 'Picual') in the different Health status (Asymptomatic and Symptomatic). (I) represents fungal richness dataset and (II) represents fungal richness dataset excluding both pathogenic fungi $V$. oleaginea and P. cladosporioides.

Table 2. Details of the two-factor PERMANOVA test on the fungal dataset for the factors; "Health status" Asymptomatic and Symptomatic (2 levels, fixed) and "Cultivar" ‘Galega vulgar', 'Cobrançosa' and 'Picual' ( 3 levels, random) for all variables analyzed. Bold values highlight significant effects and interactions $(\mathrm{p}<0.05)$.

\begin{tabular}{cccccccc}
\hline & Source of Variation & $\begin{array}{c}\text { Degrees of } \\
\text { Freedom }\end{array}$ & $\begin{array}{c}\text { Sum of } \\
\text { Squares }\end{array}$ & $\begin{array}{c}\text { Mean } \\
\text { Squares }\end{array}$ & Pseudo-F & Perms & P(perm) \\
\hline Fungal & Health status & 1 & 369990 & 369990 & 23.942 & 38 & $\mathbf{0 . 0 0 1 4}$ \\
richness & Cultivar & 2 & 34596 & 17298 & 9.7174 & 9944 & $\mathbf{0 . 0 0 0 1}$ \\
- & Health status x Cultivar & 2 & 30908 & 15454 & 8.6813 & 9948 & $\mathbf{0 . 0 0 0 1}$ \\
- & Residual & 294 & 523360 & 1780 & - & - & - \\
- & Total & 299 & 958850 & - & - & & - \\
\hline Fungal & Health status & 1 & 914.28 & 914.28 & 0.71023 & 360 & 0.5397 \\
richness* & Cultivar & 2 & 14325 & 7162.5 & 53.698 & 9920 & $\mathbf{0 . 0 0 0 1}$ \\
- & Health status x Cultivar & 2 & 2581 & 1290.5 & 9.6749 & 9941 & $\mathbf{0 . 0 0 0 1}$ \\
- & Residual & 275 & 36681 & 133.39 & - & - & - \\
- & Total & 280 & 54692 & - & - & - & - \\
\hline
\end{tabular}

\footnotetext{
* means PERMANOVA test on the fungal dataset excluding both pathogenic fungi $V$. oleaginea and P. cladosporioides.
} 
These results are supported by the PCO ordination plot and clearly reflect a distinct pattern for fungal richness between asymptomatic and asymptomatic olive plants. The PCO ordination of the endophytic richness showed that the first two components (PCO1, 44.72\% and PCO2, 24.24\%) accounted for $68.9 \%$ of the variability of the data (Figure 2).

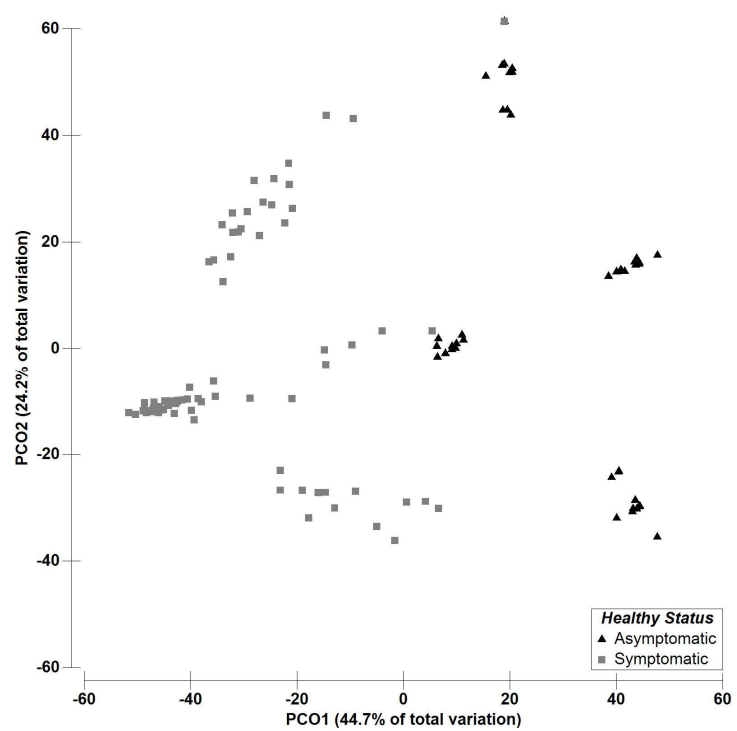

Figure 2. Principal coordinates analysis PCO based on the fungal richness dataset for the factor "Health status" Asymptomatic and Symptomatic (2 levels, fixed). PCO1 $=24.2 \%$ and $\mathrm{PCO} 2=44.7 \%$.

The mean fungal richness \pm SE excluding both pathogenic fungi $V$. oleaginea and P. cladosporioides was $1.79 \pm 0.07$ in asymptomatic olive plants and $1.93 \pm 0.11$ in symptomatic plants (Figure 1-II). In addition, PERMANOVA analyses were performed excluding both pathogenic fungi $V$. oleaginea and P. cladosporioides, showing no significant differences in fungal richness between symptomatic and asymptomatic (Factor "health status", $\mathrm{p}=0.5397$ ).

At the cultivar level, the mean fungal richness \pm SE was $3.61 \pm 0.17$ in 'Galega vulgar' followed by $2.25 \pm 0.11$ in 'Cobrançosa', and $2.02 \pm 0.11$ in 'Picual' (Figure 1-I). PERMANOVA analyses showed significant $(\mathrm{p}=0.0001)$ higher fungal richness in 'Galega vulgar' when compared to 'Cobrançosa' and 'Picual' and no significant differences $(\mathrm{p}=0.07)$ between these last two cultivars. These results are supported by the PCO ordination plot and clearly reflect a high variability for fungal richness between 'Galega vulgar' and the other cultivars. The PCO ordination of the endophytic richness showed that the first two components (PCO1, 44.72\% and $\mathrm{PCO} 2,24.24 \%$ ) accounted for $68.9 \%$ of the variability of the data (Figure 3).

At the cultivar level, the mean fungal richness \pm SE excluding both pathogenic fungi $V$. oleaginea and P. cladosporioides was $2.80 \pm 0.11$ in 'Galega vulgar' followed by $1.52 \pm 0.08$ in 'Cobrançosa' and $1.26 \pm 0.08$ in 'Picual' (Figure 1-II). PERMANOVA analyses excluding both pathogenic fungi still showed significant $(\mathrm{p}=0.0001)$ higher fungal richness in 'Galega vulgar' when compared to 'Cobrançosa' and 'Picual' and no significant differences $(p=0.3464)$ between these last two cultivars. Individual pairwise comparisons confirmed the high variability in terms of fungal richness, with consistent higher values in symptomatic plants compared to asymptomatic plants at each cultivar; 'Cobrançosa' (Pairwise Tests, $\mathrm{p}$ symptomatic vs. asymptomatic $=0.0001)$, 'Galega Vulgar' (Pairwise Tests, $\mathrm{p}_{\text {symptomatic vs. asymptomatic }}=0.0001$ ) and 'Picual' (Pairwise Tests, $\mathrm{p}$ symptomatic vs. asymptomatic $=0.0001$ ). In symptomatic plants, individual pairwise comparisons between cultivars showed significant higher fungal richness in 'Galega vulgar' compared to 'Cobrançosa' (Pairwise Tests, $\mathrm{p}$ 'Galega vulgar' vs. 'Cobrançosa' $=0.0001$ ) and 'Picual' (Pairwise Tests, $\mathrm{p}$ 'Galega vulgar' vs. 'Picual' $=0.0001$ ), and no significant differences between 'Cobrançosa' and 'Picual' (Pairwise Tests, $\mathrm{p}$ 'Cobrançosa' vs. 'Picual' $=0.5121$ ). In asymptomatic plants, individual pairwise comparisons between cultivars also showed significant higher fungal 
richness in 'Galega vulgar' compared to 'Cobrançosa' (Pairwise Tests, $\mathrm{p}$ 'Galega vulgar' vs. 'Cobrançosa' $=$ 0.0021 ) and 'Picual' (Pairwise Tests, $\mathrm{p}$ 'Galega vulgar' vs. 'Picual' $=0.0001$ ), and no significant differences between 'Cobrançosa' and 'Picual' (Pairwise Tests, $\mathrm{p}^{\prime}$ Cobrançosa' vs. 'Picual' $=0.0583$ ).

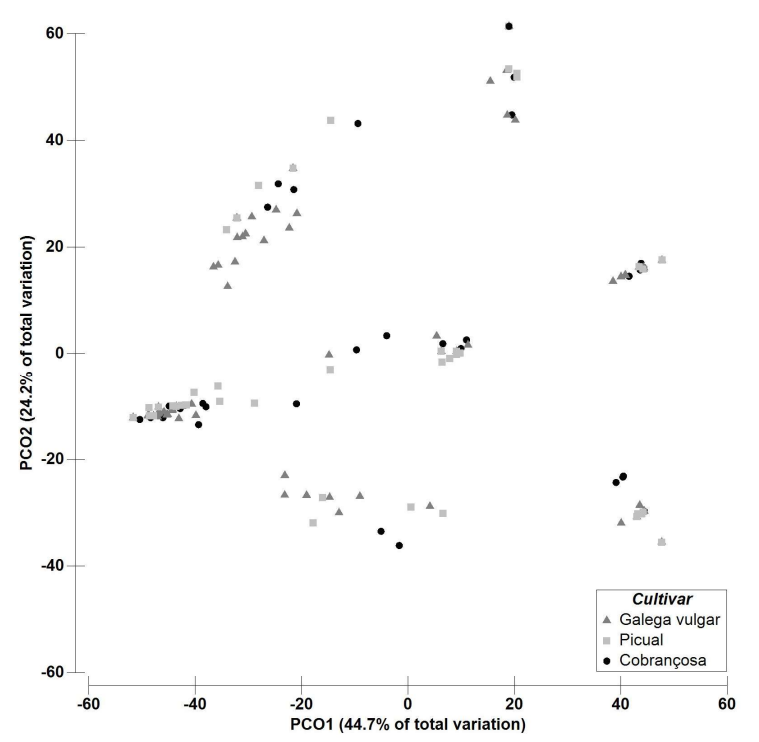

Figure 3. Principal coordinates analysis PCO based on the fungal richness dataset for the factor "Cultivar" 'Galega vulgar', 'Cobrançosa' and 'Picual' (3 levels, random). PCO1 $=24.2 \%$ and PCO2 = 44.7\%.

Individual pairwise comparisons, excluding both pathogenic fungi, showed that only 'Galega Vulgar' presented significant higher values of fungal richness in symptomatic plants when compared to asymptomatic plants (Pairwise Tests, $\mathrm{p}_{\text {symptomatic vs. asymptomatic }}=0.0001$ ), with 'Cobrançosa' and 'Picual' showing no significant differences (Pairwise Tests, $p$ symptomatic vs. asymptomatic $=0.2569$ and Pairwise Tests, $\mathrm{p}$ symptomatic vs. asymptomatic $=0.3437$, respectively). In addition, when both pathogenic fungi were excluded, in symptomatic plants, individual pairwise comparisons between cultivars still showed significant higher fungal richness in 'Galega vulgar' compared to 'Cobrançosa' (Pairwise Tests, $\mathrm{p}$ 'Galega vulgar' vs. 'Cobrançosa' $=0.0001$ ) and 'Picual' (Pairwise Tests, $\mathrm{p}$ 'Galega vulgar' vs. 'Picual' $=0.0001$ ), and no significant differences between 'Cobrançosa' and 'Picual' (Pairwise Tests, $\mathrm{p}$ 'Cobrançosa' vs. 'Picual' $=0.6195)$; in asymptomatic plants, individual pairwise comparisons between cultivars still showed significant higher fungal richness in 'Galega vulgar' compared to 'Cobrançosa' (Pairwise Tests, $\mathrm{p}$ 'Galega vulgar' vs. 'Cobrançosa' $=0.0022)$ and 'Picual' (Pairwise Tests, p 'Galega vulgar' vs. 'Picual' $=0.0001$ ), and no significant differences between 'Cobrançosa' and 'Picual' (Pairwise Tests, p 'Cobrançosa' vs. 'Picual' $=0.0559$ ).

\section{Discussion}

In the present study, the fungal diversity associated with olive leaf spots in the presence of two major pathogens (V. oleaginea and P. cladosporioides), was investigated. Three different olive cultivars, with different susceptibilities to both pathogens, grown in the Alentejo region, were tested. Sampling was performed in spring, when lesions caused by V. oleaginea and P. cladosporioides are more evident.

Overall, 788 fungal isolates, from a total of 300 olive trees, were obtained and classified into 21 OTUs. Regardless of the health status or the cultivar, Ascomycota was clearly the most abundant Phylum, and Basidiomycota showed the lowest percentage of isolates. Interestingly, isolates from the Phylum Basidiomycota were not isolated in vitro and were only identified when direct total leaf DNA was used. This finding is possibly related to the media used and to the rapid colonization of fungi from Ascomycota that inhibit the growth of slow growing fungi, and demonstrate the importance of the use of these two methodologies to isolate a broader range of fungi. Despite that, proportions of these two Phyla obtained here are similar to other studies in olive as well as in other woody plants [28,31-33]. Within 
the Ascomycota, the class Dothideomycetes was the most representative followed by Leotiomycetes, Sordariomycetes, and Eurotiomycetes. The high incidence of the Dothideomycetes observed here is mainly due to the high number of isolates belonging to V. oleaginea, Alternaria sp., Epicoccum sp., and Foliophoma sp. as well as to P. cladosporioides. The Leotiomycetes identified were Chalara sp. and Botrytis sp. that, together with the above Dothideomycetes OTUs, represent nearly $80 \%$ of the fungal diversity found in this study. The Dothideomycetes is one of the largest classes and has shown to lead the diversity in the olive tree, as well as in other crops [28,31-33] while it comprises several plant pathogenic species, but also some antagonistic species. Within the Basidiomycota, the class Tremellomycetes was the most representative, mostly due to Cryptococcus sp. and Bullera sp.

The analysis of fungal richness in both health status, revealed significant higher values in the cultivar 'Galega vulgar' followed by 'Cobrançosa', which in turn did not show significant differences to 'Picual'. In addition, 'Galega vulgar' also showed a higher fungal diversity when compared to the other cultivars, with the presence of five exclusive OTUs. The fact that over $80 \%$ of the Portuguese orchards are composed of trees from cv 'Galega vulgar', demonstrates the good establishment and adaptation of this cultivar in Portugal, and may partially explain the high values of fungal richness, and which are consistent with previous studies [28-30]. Other factors involving the chemistry of the plant, and certain types of phenolics in olive tissues have also been reported to determine the presence of some fungi and resistance to pathogens [34,35].

Concerning plant health status, the fungal communities revealed significant higher richness in symptomatic compared to asymptomatic plants in all cultivars, mostly due to the high number of isolates (230) from the pathogens V. oleaginea and P. cladosporioides that contribute to near $70 \%$ of the total isolates and that were not detected in any asymptomatic plants. However, when both pathogens were excluded from the analysis, only 'Galega vulgar' still maintained higher significant values of fungal richness in symptomatic plants when compared to asymptomatic plants, with 'Cobrançosa' and 'Picual' showing no significant differences between symptomatic and asymptomatic plants. Interestingly, despite the long latent period these two pathogens usually present, none of them was detected as latent, in asymptomatic leaves. This may be due to the fact that asymptomatic leaves were collected from trees with no apparent symptoms; meaning that pathogens may indeed not be present or they could be controlled by antibiosis or for space and nutrient competition by other endophytes. The incidence of $P$. cladosporioides and/or V. oleaginea in all symptomatic plants seems to confirm the role and shows the aggressiveness of these pathogens in the leaf spots. P. cladosporioides is the causal agent of olive cercosporiosis and $V$. oleaginea is the causal agent of peacock spot disease. This is not the case of other diseases, such as olive anthracnose, in which the causal agent, Colletotrichum sp., is frequently found as endophyte without causing any symptoms [30,31]. Interestingly, high levels of $V$. oleaginea were found in cv. 'Galega vulgar', known to be somewhat resistant to peacock disease, contrary to the other cultivars used, where it would be expected that P. cladosporioides dominates the pathogenic species.

Almost all of the remaining isolates found in symptomatic plants $(27 \%)$ belonged to Chalara sp. and Foliophoma sp., being among the species most frequent in symptomatic trees. Foliophoma sp. has already been reported as the most abundant genera in trees infected with $V$. oleaginea [10]. Like Chalara sp., species within the Foliophoma genus have been described as saprophytes but also as pathogens causing dieback and shoot necrosis in olive [36-38]. No such symptoms were observed in the olive trees used in this study, however these two highly detected genera in symptomatic plants, can be a secondary effect of the disease, behaving as opportunistic pathogens and increasing the severity of the infection.

V. oleaginea, P. cladosporioides, Chalara sp., and Foliophoma sp. represent over $90 \%$ of the isolates detected in symptomatic plants. Differences on fungal composition between symptomatic and asymptomatic plants are clear, as seen in the PCO analysis (Figure 2). Although Alternaria sp. and Epicoccum sp. were present in both symptomatic and asymptomatic plants, in asymptomatic plants over $90 \%$ of the isolates are represented by these two OTUs, as opposed to $11 \%$ in symptomatic plants. Despite some Alternaria species having been reported to cause damages on olive [38-41], 
most species are saprophytic and/or endophytic. In this study no typical symptoms of pathogenicity caused by Alternaria sp. were seen in the olive trees used. The high incidence of these two genera in fungal communities inhabiting olive and other plants has been previously reported [30,42], however data comparing their presence with $V$. oleaginea and/or P. cladosporioides are inexistent. Alternaria and Epicoccum genera are both members of the Dothideomycetes, which are known to possess effective antagonistic mechanisms [42-46].

All remaining OTUs are represented by less than 3.5\% each, and were either exclusive of symptomatic or asymptomatic plants, except for Aureobasidium sp. that appeared in both symptomatic and asymptomatic plants. This finding was expected since Aureobasidium sp. is one of the most abundant fungi present in the phyllosphere of several plants, including olive, where it has been isolated from the complex of saprophytic fungi that forms a sooty mold that may have an impact on olive fruit quality [30,47-50]. It is however often described as non-pathogenic and has also been reported as an effective bio-control agent due to its antagonistic activity against several pathogens [51-54]. Botrytis sp. isolates were only detected in symptomatic plants; it is a known pathogenic species, but no typical symptoms of this pathogen were seen in the sampled trees, suggesting that this pathogen is latent; its common occurrence as endophyte has been reported [42].

Diaporthe sp., Arthrinium sp., Aspergillus sp., and Fusarium sp. isolates were only detected in asymptomatic trees, and at low abundances $(<2.5 \%)$. All these fungi have been reported as pathogens in a wide range of plant species, including olive $[38,55,56]$. The fact that they have been found in symptomless plants suggests that these fungi may colonize and establish latent infections. The analysis of the sequences of Diaporthe sp. and Fusarium sp. did not allow the identification to the species level, however, these genera comprise species that are pathogenic to olive, causing wilts, rots, cankers, and dieback symptoms $[57,58]$. Fusarium sp., Aspergillus sp. and Diaporthe sp. have been profiled for their volatile compounds and antifungal substances were detected $[42,59,60]$. They have already shown antagonistic activity against several pathogens namely Colletotrichum in olive and also in other plants.

In addition to the two pathogenic fungi focused in this study, another five OTUs were exclusive of symptomatic trees, although represented by less than 1\% (Bullera sp., Erythrobasidium sp., Neofusicoccum sp., Saccharata sp., and Sporobolomyces sp.). From these five fungi, Neofusicoccum sp. have been described as endophytes or as plant pathogens that can cause infections on olive, causing shoot cankers, and dieback, and Bullera sp. comprise species with antagonistic functions. Nevertheless, currently available data on these species does not enable assumptions on the role of these fungi on olive to be supported.

In spite of the increasing number of studies concerning fungal diversity in olive, there is still more to learn about the associations they establish with known pathogens. To the best of our knowledge, this is the first study concerning fungal communities associated with these diseases. In conclusion, despite being performed in a localized area, this study showed a high fungal composition, similar to previous studies performed in different regions [28,31]. In this study, when olive plants from different cultivars, both asymptomatic and presenting leaf spots symptoms, were screened for fungal communities, two major groups of fungi were detected regardless of the cultivar: $90 \%$ of the isolates found in symptomatic plants belonged to V. oleaginea, P. cladosporioides, Chalara sp., and Foliophoma sp. and in asymptomatic plants, $90 \%$ of the isolates belonged to Alternaria sp. and Epicoccum sp. None of the dominant OTUs found in symptomatic trees were found in asymptomatic trees. This is very interesting, as Alternaria sp. and Epicoccum sp. seem to dominate the niches in asymptomatic plants.

Due to the known antagonistic role of these two genera, it would be interesting to study if there is any competitive action against these fungal plant pathogens, namely if their well establishment is preventing the development of putative later arriving species, such as $V$. oleaginea or P. cladosporioides.

It would be quite interesting to test if antagonistic activities exist and differ according to the order of infection of the several fungi, or if Alternaria sp. and Epicoccum sp. isolates, found in symptomless trees, present differences in genetic sequences or in gene expression from the Alternaria sp. and Epicoccum sp. isolates found in symptomatic trees. These data may be useful from a practical point of view with the aim of developing new more effective and less impacting means for disease management. 


\section{Materials and Methods}

\subsection{Sampling Collection}

Leaf samples were collected in the spring of 2017 (from April to May) from olive trees belonging to three main cultivars 'Galega vulgar', 'Cobrançosa', and 'Picual', randomly selected within a field of 32 ha, near Monforte (Alentejo, south Portugal), where epidemic outbreaks of leaf spot disease occur on a yearly basis. The sampled orchard included programmed applications of fungicide and insecticide products such as copper hydroxide, trifloxystrobin, deltamethrin, and dimethoate.

Due to the difficulty in distinguishing peacock and cercospora leaf spots, both diseases were treated together; trees presenting leaf spots (either peacock or cercospora, or both) were considered 'symptomatic' and trees with apparently no symptoms were considered 'asymptomatic'. All asymptomatic leaves were collected from trees with apparently no leaf spots in general. In addition, whenever possible, asymptomatic trees were chosen that had never presented these types of symptoms in the previous years. All olive trees sampled were 10 to 15 years old and of medium size. Sampling consisted in the collection of ca. 100 olive leaves around the whole tree at a height of ca. $2 \mathrm{~m}$. A total of 300 samples (100 trees $\times 3$ cultivars), half from symptomatic trees and half from trees with apparently no symptoms were taken. Each tree was treated as a sample.

To minimize the detection of epiphytic fungi as well as of microorganisms occasionally adherent to the leaf surface, leaf samples were rapidly disinfected with a sequence of 3 min immersions in $96 \%$ ethanol, 3\% sodium hypochlorite solution, 70\% ethanol, washed in ultra-pure water, and dried in sterile paper [30]. Leaves were stored at $4{ }^{\circ} \mathrm{C}$ until further processing. All samples were used for both fungal isolation (prior to DNA extraction) and for direct DNA extraction.

\subsection{Fungal Isolation and DNA Extraction}

Olive leaves were cut into small pieces of ca. $1 \mathrm{~cm}$ and placed on $9 \mathrm{~cm}$ diameter Petri dishes (five pieces per plate) containing Potato Dextrose Agar medium (PDA) (Merck, Darmstadt, Germany), at $25^{\circ} \mathrm{C} \pm 3{ }^{\circ} \mathrm{C}$ for 5 to 12 days. Colonies were then transferred to a new PDA plate for isolation. Mycelia from isolated fungi were ground in liquid nitrogen and stored at $-80^{\circ} \mathrm{C}$ until DNA extraction.

Both total DNA from samples and DNA from isolated fungi were extracted using the cetyltrimethyl ammonium bromide (CTAB) method [61], with some modifications [32]. For each sample, total DNA was extracted from ca. $500 \mathrm{mg}$ of leaf material and ca. $250 \mathrm{mg}$ of mycelium powder. DNA concentration was determined by using a Quawell Q9000 micro spectrophotometer (Quawell Technology, Beijing, China).

\subsection{Fungal Molecular Identification}

Fungal ITS regions were PCR amplified by using the primers ITS1 and ITS4 [62]. Reactions were performed in a total volume of $50 \mu \mathrm{L}$ containing 30-80 ng of genomic DNA, $10 \mathrm{mM}$ Tris- $\mathrm{HCl}(\mathrm{pH}$ 8.6), $50 \mathrm{mM} \mathrm{KCl}, 1.5 \mathrm{mM} \mathrm{MgCl2,} 0.2 \mathrm{mM}$ dNTPs (Fermentas, Waltham, MA, USA), $0.25 \mu \mathrm{M}$ of each primer and 2.5 U DreamTaq DNA polymerase (Fermentas, Waltham, MA, USA). The amplification reaction was performed in a Thermal Cycler (Bio-Rad, Hercules, CA, USA) under the following temperature conditions: $95^{\circ} \mathrm{C}$ for $2 \mathrm{~min}, 40$ cycles of $95^{\circ} \mathrm{C}$ for $30 \mathrm{~s}, 54{ }^{\circ} \mathrm{C}$ for $1 \mathrm{~min}, 72{ }^{\circ} \mathrm{C}$ for $1 \mathrm{~min}$, and a final extension of $72{ }^{\circ} \mathrm{C}$ for $10 \mathrm{~min}$. Amplified products were electrophoresed in $1 \%$ agarose gel and purified using DNA Clean \& Concentrator (Zymo Research, Irvine, CA, USA). PCR products from DNA of isolated fungi were sequenced in both strands by Macrogen (Madrid, Spain). PCR products from direct DNA extraction were further cloned into pGEM-T easy vector (Promega, Madison, WI, USA) in accordance with the manufacturer's instructions. Transformed E. coli JM109 cells were grown overnight at $37{ }^{\circ} \mathrm{C}$ at $175 \mathrm{rpm}$ in LB medium ( $1 \%$ tryptone, $0.5 \%$ yeast extract and $0.5 \% \mathrm{NaCl}$, pH 7.5) with $100 \mathrm{mg} / \mathrm{mL}$ ampicillin. Plasmid DNA from 5 randomly selected colonies/samples was extracted using GenElute HP Plasmid Miniprep (Merck, Darmstadt, Germany) in accordance with the manufacturer's instructions. Clones were sequenced in both strands by Macrogen (Madrid, Spain). 
Five ITS sequences/samples were determined. All sequences were analyzed using Bioedit Sequence Alignment Editor v.7.2.3 [63]. Taxonomic identification was done through the search for the closest sequence matches, using Basic Local Alignment Search Tools (BLAST) against the National Center for Biotechnology Information (NCBI) sequence database. Isolates were identified at species or genus level and classified as an Operational Taxonomic Unit (OTU).

\subsection{Data Analysis}

Univariate and multivariate analyses were performed to detect significant differences in total richness in the endophytic fungi in the two factors "Health status" and "Cultivar". The statistical analyses of the data were performed using the PRIMER v6 software package [64] with the PERMANOVA add-on package [65]. The PERMANOVA analysis was carried out following the two factor design: Health status; "Symptomatic and Asymptomatic" (2 levels, fixed) and Cultivar: "Galega vulgar, Cobrançosa, and Picual" (3 levels, random). A two-way permutational analysis of variance (PERMANOVA) was applied to test the hypothesis that significant differences existed in the total richness in the fungi among the factors health status and cultivar. Total fungal data were square root transformed in order to scale down the importance of highly abundant endophytic fungi and therefore increase the importance of the less abundant ones in the analysis of similarity between communities. The PERMANOVA analysis was conducted on a Bray-Curtis similarity matrix [66]. The null hypothesis was rejected at a significance level $<0.05$ (if the number of permutations was lower than 150, the Monte Carlo permutation $p$ was used). Whenever significant interactions in the effects of the factors were detected, these were examined using a posteriori pairwise comparisons, using 9999 permutations under a reduced model. All PERMANOVA procedures were also performed on the fungal richness data excluding both pathogenic fungi $V$. oleaginea and P. cladosporioides. The similarity in the endophytic fungi richness identified on each health status and cultivar was plotted by Principal coordinates analysis (PCO) using the Bray-Curtis similarity measure based on each of the two factors; health status and cultivar. The relative contribution of each fungus to the average of similarity between a priori defined groups; each health status and cultivar; was calculated using the one way-crossed similarity percentage analysis (SIMPER, cut-off percentage: 100\%).

Author Contributions: Conceptualization, C.V. and M.F.; methodology, C.V., P.M., and M.C.; formal analysis, C.V. and P.M.; investigation, C.V., M.L., and M.F.; resources, M.F.; writing-original draft preparation, C.V and P.M.; writing - review and editing, C.V., P.M., M.L., M.C., and M.F.; funding acquisition, C.V., P.M. and M.F.

Funding: This work was funded by the project "Control of olive anthracnose through gene silencing and gene expression using a plant virus vector" with the reference ALT20-03-0145-FEDER-028263 and by the project "Development of a new virus-based vector to control TSWV in tomato plants" with the reference ALT20-03-0145-FEDER-028266, both co-financed by the European Union through the European Regional Development Fund, under the ALENTEJO 2020 (Regional Operational Program of the Alentejo), ALGARVE 2020 (Regional Operational Program of the Algarve) and through the Foundation for Science and Technology (FCT), in its national component. This work is also funded by National Funds through FCT under the Project UID/AGR/00115/2019.

Conflicts of Interest: The authors declare no conflict of interest. The funders had no role in the design of the study; in the collection, analyses, or interpretation of data; in the writing of the manuscript, or in the decision to publish the results.

\section{References}

1. IOC. Available online: http://www.internationaloliveoil.org/ (accessed on 4 June 2018).

2. Grieco, F.; Alkowni, R.; Saponari, M.; Pantaleo, V.; Savino, V.; Martelli, G.P. Molecular detection of olive-infecting viruses. Acta Hortic. 2002, 586, 737-740. [CrossRef]

3. Sistani, F.; Ramezanpour, S.; Nasrollanejad, S. Field Evaluation of Different Fungicides Application to Control Olive Leaf Spot. Aust. J. Basic Appl. Sci. 2009, 3, 3341-3345.

4. Moral, J.; Alsalimiya, M.; Roca, L.; Díez, C.; León, L.; de la Rosa, R.; Barranco, D.; Rallo, L.; Trapero, A. Relative susceptibility of new olive cultivars to Spilocaea oleagina, Colletotrichum acutatum, and Pseudocercospora cladosporioides. Plant Dis. 2015, 99, 58-64. [CrossRef] [PubMed] 
5. Trapero, A.; Blanco, M. Enfermedades. In El cultivo del Olivo; Barranco, D., Fernandez-Escobar, R., Rallo, L., Eds.; Mundi Prensa-Junta de Andalucia: Madrid, Spain, 2004; pp. 510-514.

6. Vossen, P. Timing sprays for control peacock spot and olive knot disease. Olive News Univ. Calif. Coop. Ext. Glenn Cty. 2004, 7, 11.

7. Avila, A.; Groenewald, J.; Trapero, A.; Crous, P. Characterisation and epitypification of Pseudocercospora cladosporioides, the causal organism of Cercospora leafspot of olives. Mycol. Res. 2005, 109, 881-888. [CrossRef] [PubMed]

8. Graniti, A.; Frisullo, S.; Pennisi, A.; Magnano di San Lio, G. Infections of Glomerella cingulata on olive in Italy. EPPO Bull. 1993, 23, 457-465. [CrossRef]

9. Shabi, E.; Birger, R.; Lavee, S.; Klein, I. Leaf spot (Spilocaea oleaginea) on olive in Israel and its control. Acta Horticult. 1994, 356, 390-394. [CrossRef]

10. Viruega, J.; Moral, J.; Roca, L.; Navarro, N.; Trapero, A. Spilocaea oleagina in Olive Groves of Southern Spain: Survival, Inoculum Production, and Dispersal. Plant Dis. 2013, 97, 1549-1556. [CrossRef]

11. Vega, J.; Cabezas, D. El “repilo plomizo" del olivo, causado por Cercospora cladosporioides Sacc., enfermedad presente en Espana. Bol. Sanid. Veg. Plagas 1985, 11, 31-35.

12. Henricot, B.; Gorton, C.; Denton, J.; Denton, G. Pseudocercospora cladosporioides, the cause of leaf spot on olive, a pathogen new to the United Kingdom. Plant Pathol. 2009, 58, 803. [CrossRef]

13. Benitez, Y.; Botella, M.; Trapero, A.; Alsalimiya, M.; Caballero, J.; Dorado, G.; Munoz-Blanco, J. Molecular analysis of the interaction between Olea europaea and the biographic fungus Spilocaea oleagina. Mol. Plant Pathol. 2005, 6, 425-438. [CrossRef] [PubMed]

14. Civantes, M. Olive Pest and Disease Management; IOCC: Towson, MD, USA, 1999.

15. Figueres, G. Repilos del Olivo: Ataque en Fruto; Phytoma España: Valencia, Spain, 1991; pp. 31-36.

16. Fragoso, R. Botanica Criptogamica Agricola; Espasa Calpe: Madrid, Spain, 1927.

17. Obanor, F.; Jaspers, M.; Jones, E.; Walter, M. Greenhouse and Field Evaluation of Fungicides for Control of Olive Leaf Spot in New Zealand. Crop Prot. 2008, 27, 1335-1342. [CrossRef]

18. Sanei, S.; Razav, S. Survey of Spilocaea oleagina, causal agent of olive leaf spot, in North of Iran. J. Yeast Fungal Res. 2011, 2, 33-38. [CrossRef]

19. Guechi, A.; Girre, L. Sources of Cycloconium Oleaginum (Cast.) conidia for infection of olive leaves and conditions determining leaf spot disease development in the region of Sétif, Algeria. Mycopathologia 1994, 125, 163-171. [CrossRef]

20. Lops, F.; Frisullo, S.; Rossi, V. Studies on the spread of the olive scab pathogen Spilocaea oleagina. Bull. OEPP/EPPO Bull. 1993, 23, 385-387. [CrossRef]

21. Romero, J.; Agustí-Brisach, C.; Roca, L.F.; Moral, J.; González-Domínguez, E.; Rossi, V.; Trapero, A. A long-term study on the effect of agroclimatic variables on olive scab in Spain. Crop Prot. 2018, 114, 39-43. [CrossRef]

22. Roubal, C.; Regis, S.; Nicot, P.C. Field models for the prediction of leaf infection and incubation period of Fusicladium oleagineum on olive based on rain, temperature and relative humidity. Plant Pathol. 2013, 62, 657-666. [CrossRef]

23. Viruega, J.R.; Roca, L.F.; Moral, J.; Trapero, A. Factors affecting infection and disease development on olive leaves inoculated with Fusicladium oleagina. Plant Dis. 2011, 95, 1139-1146. [CrossRef]

24. Teviotdale, B.; Sibbett, G.; Harper, D. Several Copper Fungicides Control Olive Leaf Spot. Calif. Agric. 1989, 43, 30-31.

25. Malavolta, C.; Perdikis, D. IOBC technical guidelines III. Guidelines for integrated production of olives. IOBC/WPRS Bull. 2012, 77, 1-19.

26. HOA. Hunter Olive Handbook: A Practical Guide for Sustainable Olive Production; Australian eBook Publisher: Acacia Ridge, QLD, Australia, 2016.

27. Roca, L.; Horchani, H.; Trapero, A. Search for alternatives to copper for the control of olive leaf spot caused by Fusiciadium oleagineum. In Proceedings of the 4th European Meeting of the 1OBC/wprs working Group Integrated Protection of Olive Crops, Córdoba, Spain; 2009; p. 54.

28. Gomes, T.; Pereira, J.A.; Benhadi, J.; Lino-Neto, T.; Baptista, P. Endophytic and Epiphytic Phyllosphere Fungal Communities Are Shaped by Different Environmental Factors in a Mediterranean Ecosystem. Microb. Ecol. 2018, 76, 668-679. [CrossRef] [PubMed] 
29. Martins, F.; Pereira, J.A.; Bota, P.; Bento, A.; Baptista, P. Fungal endophyte communities in above- and belowground olive tree organs and the effect of season and geographic location on their structures. Fungal Ecol. 2016, 20, 193-201. [CrossRef]

30. Materatski, P.; Varanda, C.; Carvalho, T.; Dias, A.; Campos, M.; Rei, F.; Félix, M. Spatial and temporal variation of fungal endophytic richness and diversity associated to the phyllosphere of olive cultivars. Fungal Biol. 2019, 123, 66-76. [CrossRef] [PubMed]

31. Abdelfattah, A.; Nicosia, M.; Cacciola, S.; Droby, S.; Schena, L. Metabarcoding analysis of fungal diversity in the phyllosphere and carposphere of olive (Olea europaea). PLoS ONE 2015, 10, e0131069. [CrossRef] [PubMed]

32. Materatski, P.; Varanda, C.; Carvalho, T.; Dias, A.; Campos, M.; Rei, F.; Félix, M. Diversity of Colletotrichum Species Associated with Olive Anthracnose and New Perspectives on Controlling the Disease in Portugal. Agronomy 2018, 8, 301. [CrossRef]

33. Varanda, C.M.R.; Oliveira, M.; Materatski, P.; Landum, M.; Clara, M.I.E.; Félix, M.R. Fungal endophytic communities associated to phyllospheres of grapevine cultivars under different types of management. Fungal Biol. 2016, 120, 1525-1536. [CrossRef] [PubMed]

34. Fang, W.; Yang, L.; Zhu, X.; Zeng, L.; Li, X. Seasonal and Habitat Dependent Variations in Culturable Endophytes of Camellia sinensis. J. Plant Pathol. Microb. 2013, 4, 169. [CrossRef]

35. Moral, J.; Xaviér, C.; Roca, L.; Romero, J.; Moreda, W.; Trapero, A. La Antracnosis del olivo y su efecto en la calidad del aceite. Grasas Aceites 2014, 65, e028. [CrossRef]

36. Ivic, D.; Ivanovic, A.; Milicevic, T.; Cvjetkovic, B. Shoot necrosis of olive caused by Phoma incompta, a new disease of olive in Croatia. Phytopathol. Mediterr. 2010, 49, 414-416.

37. Koukol, O. New species of Chalara occupying coniferous needles. Fungal Divers. 2011, 49, 75-91. [CrossRef]

38. Lo Piccolo, S.; Mondello, V.; Giambra, S.; Conigliaro, G.; Torta, L.; Burruano, S. Arthrinium phaeospermum, Phoma cladoniicola and Ulocladium consortiale, New Olive Pathogens in Italy. J. Phytopathol. 2014, 162, 258-263. [CrossRef]

39. Basim, E.; Basim, H.; Abdulai, M.; Baki, D.; Oztürk, N. Identification and characterization of Alternaria alternata causing leaf spot of olive tree (Olea europaea) in Turkey. Crop Prot. 2017, 92, 79-88. [CrossRef]

40. Bourbos, V.; Skoundridakis, M.; Metzidakis, I. Alternaria alternata: A new disease of leafy cuttings of olive shoots. Acta Hortic. 1999, 474, 585-587. [CrossRef]

41. Lagogianni, C.; Tjamos, E.; Antoniou, P.; Tsitsigiannis, D. First Report of Alternaria alternata as the Causal Agent of Alternaria Bud and Blossom Blight of Olives. Plant Dis. 2017, 101, 2151. [CrossRef]

42. Landum, M.C.; Félix, M.d.R.; Alho, J.; Garcia, R.; Cabrita, M.J.; Rei, F.; Varanda, C.M.R. Antagonistic activity of fungi of Olea europaea L. against Colletotrichum acutatum. Microbiol. Res. 2016, 183, 100-108. [CrossRef] [PubMed]

43. Dugan, F.; Lupien, S.; Grove, G. Incidence, Aggressiveness and In Planta Interactions of Botrytis cinerea and other Filamentous Fungi Quiescent in Grape Berries and Dormant Buds in Central Washington State. J. Phytopathol. 2002, 150, 375-381. [CrossRef]

44. Musetti, R.; Polizzotto, R.; Vecchione, A.; Borselli, S.; Zulini, L.; D'Ambrosio, M.; Sanitá di Toppi, L.; Pertot, I. Antifungal activity of diketopiperazines extracted from Alternaria alternata against Plasmopara viticola: An ultrastructural study. Micron 2007, 38, 643-650. [CrossRef] [PubMed]

45. Larena, I.; Linan, M.; Melgarejo, P. Antibiotic Production of the Biocontrol Agents Epicoccum nigrum and Candida sake. In Proceedings of the 6th Conference EFPP, Prague, Czech Republic, 8-14 September 2002; pp. 205-208.

46. Martini, M.; Musetti, R.; Grisan, S.; Polizzotto, R.; Borselli, S.; Pavan, F.; Osler, R. DNA-dependent detection of the grapevine fungal endophytes Aureobasidium pullulans and Epicoccum nigrum. Plant Dis. 2009, 93, 993-998. [CrossRef] [PubMed]

47. Andrews, J.; Harris, R.; Spear, R.; Lau, G.; Nordheim, E. Morphogenesis and adhesion of Aureobasidium pullulans. Can. J. Microbiol. 1994, 40, 6-17. [CrossRef]

48. Deshpande, M.; Rale, V.; Lynch, J. Aureobasidium pullulans In applied microbiology: A status report. Enzyme Microb. Technol. 1992, 14, 514-527. [CrossRef]

49. Grabowski, M. The study of new fungus species causing apple sooty blotch. Folia Hort Ann. 2007, 19, 89-97. 
50. Pancher, M.; Ceol, M.; Corneo, P.; Longa, C.; Yousaf, S.; Pertot, I.; Campisano, A. Fungal endophytic communities in grapevines (Vitis vinifera L.) respond to crop management. Appl. Environ. Microbiol. 2012, 78, 4308-4317. [CrossRef] [PubMed]

51. Hartati, S.; Wiyono, S.; Hidayat, S.; Sinaga, M. Mode of Action of Yeast-Like Fungus Aureobasidium pullulans in Controlling Anthracnose of Postharvest Chili. Int. J. Sci. Basic Appl. Res. 2015, 20, 253-263.

52. Tashiro, N.; Noguchi, M.; Ide, Y.; Kuchiki, F. Sooty spot caused by Cladosporium cladosporioides in postharvest Satsuma mandarin grown in heated greenhouses. J. Gen. Plant Pathol. 2013, 79, 158-161. [CrossRef]

53. Wachowska, U.; Głowacka, K. Antagonistic interactions between Aureobasidium pullulans and Fusarium culmorum, a fungal pathogen of winter wheat. BioControl 2014, 59, 635-645. [CrossRef]

54. Wang, N.; Thomson, M.; Bodles, W.J.A.; Crawford, R.M.M.; Hunt, H.V.; Featherstone, A.W.E.A. Genome sequence of dwarf birch (Betula nana) and cross-species RAD markers. Mol. Ecol. 2013, 22, 3098-3111. [CrossRef] [PubMed]

55. Munitz, M.; Garrido, C.; Gonzalez, H.; Resnik, S.; Salas, P. Mycoflora and potential mycotoxin production of freshly harvested blueberry in Concordia, Entre Rios province, Argentina. Int. J. Fruit Sci. 2013, 13, 312-325. [CrossRef]

56. Kido, L.; Uzabakiriho, J.; Chimwamurombe, P. Isolation and identification of pathogenic fungi associated with Aloe zebrina flower malformation-First report. J. Pure Appl. Microbiol. 2012, 6, 125-129.

57. Frisullo, S.; Elshafie, H.; Mang, S. First report of two phomopsis species on olive trees in Italy. J. Plant Pathol. 2015, 97, 391-403.

58. Frisullo, S.; Carlucci, A. Minor fungal diseases of olives. In Olive Diseases and Disorders; Schena, L., Agosteo, G., Cacciola, S.O., Eds.; Transworld Research Network: Kerala, India, 2011; pp. 291-304.

59. Morath, S.; Hung, R.; Bennett, J. Fungal volatile organic compounds: A review with emphasis on their biotechnological potential. Fungal Biol. Rev. 2012, 26, 73-83. [CrossRef]

60. Siddiquee, S.; Al Azad, S.; Bakar, F.A.; Naher, L.; Kumar, S.V. Separation and identification of hydrocarbons and other volatile compounds from cultures of Aspergillus niger by GC-MS using two different capillary columns and solvents. J. Saudi Chem. Soc. 2015, 19, 243-256. [CrossRef]

61. Doyle, J.; Doyle, J. A rapid DNA isolation procedure for small quantities of fresh leaf tissue. Phytochem. Bull. 1987, 19, 11-15.

62. White, T.; Bruns, T.; Lee, S.; Taylor, J. Amplification and direct sequencing of fungal ribosomal RNA genes for phylogenetics. In PCR Protocols: A Guide to Methods and Applications; Innis, M.A., Gelfand, D.H., Sninsky, J.J., White, T.J., Eds.; Academic Press: San Diego, CA, USA, 1990; pp. 315-322.

63. Hall, T. BioEdit: A user-friendly biological sequence alignment editor and analysis program for Windows 95/98/NT. Nucleic Acids Symp. Ser. 1999, 41, 95-98.

64. Clarke, K.R.; Warwick, R.M. Changes in Marine Communities: An Approach to Statistical Analysis and Interpretation, 2nd ed.; Primer-E, P.U.K., Ed.; PRIMER-E Ltd.: Plymouth, UK, 2001.

65. Anderson, M.J.; Gorley, R.N.; Clarke, K.R. PERMANOVA A+ for PRIMER: Guide to Software and Statistical Methods; PRIMER-E: Plymouth, UK, 2008.

66. Clarke, K.; Green, R. Statistical design and analysis for a biological effects study. Marine Ecol. Prog. Ser. 1988, 46, 213-226. [CrossRef]

(C) 2019 by the authors. Licensee MDPI, Basel, Switzerland. This article is an open access article distributed under the terms and conditions of the Creative Commons Attribution (CC BY) license (http://creativecommons.org/licenses/by/4.0/). 